\title{
Two Mechanisms in Cell Adhesion Revealed by Effects of Divalent Cations
}

\author{
Masamichi J. Ueda and Masatoshi Takeichi \\ Department of Biophysics, Faculty of Science, Kyoto University, Kyoto, Japan
}

\begin{abstract}
The effect of divalent cations on cell-to-cell and cell-to-substrate adhesions was studied using two different types of chicken embryonic cells (fibroblastic and neural retina cells). $\mathrm{Mn}^{2+}, \mathrm{Co}^{2+}, \mathrm{Mg}^{2+}$ and $\mathrm{Ca}^{2+}$ were effective in promoting the aggregation of fibroblastic cells, while $\mathrm{Sr}^{2+}$ and $\mathrm{Ba}^{2+}$ were not effective. Among these ions, $\mathrm{Ca}^{2+}$ showed some unique effects on cell aggregation. Aggregation was initiated immediately after the addition of $\mathrm{Mn}^{2+}, \mathrm{Co}^{2+}$ or $\mathrm{Mg}^{2+}$ whereas with $\mathrm{Ca}^{2+}$ a lag period was always observed. When the medium contained both $\mathrm{Ca}^{2+}$ and $\mathrm{Mg}^{2+}$, the aggregate size formed was bigger than that formed with either ion at an equimolar concentration. The divalent cation dependence of fibroblastic cell adhesion to non-cellular substrate was essentially the same as that of cell-to-cell adhesion. The aggregation of neural retina cells specifically depended on the presence of $\mathrm{Ca}^{2+}$. For adhesion of neural retina cells to non-cellular substrate, however, $\mathrm{Ca}^{2+}$ was not effective, and only $\mathrm{Mn}^{2+}$ or $\mathrm{Co}^{2+}$ was effective. These results suggest two different mechanisms in cell adhesion.
\end{abstract}

Cells dispersed experimentally from animal tissues are known to reaggregate under appropriate conditions. The aggregation of cells generally requires the presence of divalent cations in the medium. Elucidation of the role of divalent cations in cell adhesion, therefore, is fundamental to a general understanding of the mechanism of cell adhesion (6). One difficulty in interpreting the results of published works on the effect of divalent cations is that the studies have been carried out in different experimental systems or used different types of cells. While the importance of $\mathrm{Ca}^{2+}$ has been repeatedly emphasized $(2,4,15,17,24)$, recent studies have shown that $\mathrm{Mg}^{2+}$ or $\mathrm{Mn}^{2+}$ is more effective than $\mathrm{Ca}^{2+}$ in promoting cell adhesion $(1,3,12,14,22,26)$.

Most animal cells are able to adhere to non-cellular substrates and to each other. It has not been demonstrated, however, whether the mechanisms of these two types of adhesion are the same. In the present study, we compared the effectiveness of various divalent cations on both cell-to-cell and cell-to-substrate adhesion.

\section{MATERIALS AND METHODS}

Cells. Fibroblastic cells and neural retina cells of chick embryos were used. For obtaining fibroblastic cells, the head skin was removed from 11-or 12-day-old chick embryos and the dermis was separated from the epidermis in $\mathrm{Ca}^{2+}$ - and $\mathrm{Mg}^{2+}$-free modified saline $\mathrm{G}$ (CMFS) (21). Fragments of the dermis were incubated in CMFS with $0.5 \%$ crude trypsin (Difco, Detroit, Mich., 1:250) and $0.01 \%$ crude collagenase (Worthington, Freehold) for 30 min at $37^{\circ} \mathrm{C}$. The dissociated cells were cultured with Eagle's MEM (Nissui, Tokyo) supplemented 
with $6 \%$ fetal calf serum (Gibco, Grand Island) and $2.2 \mathrm{~g} / 1 \mathrm{NaHCO}_{3}$ in Falcon plastic petri dishes in a water-saturated atmosphere containing $5 \% \mathrm{CO}_{2}$ for $4-5$ days until cultures reached a confluent state.

Neural retina cells were used for assay directly after dissociation of neural retinae from 8-day-old chick embryos, as described in the following section.

Preparation of cell suspensions. Fibroblastic cells in confluent state were washed with CMFS and incubated with $2 \mathrm{ml}$ of dissociation medium composed of $0.25 \%$ crude trypsin and $0.01 \%$ crude collagenase in CMFS for $15 \mathrm{~min}$ at $37^{\circ} \mathrm{C}$. After removing the medium by centrifugation $(160 \times \mathrm{g}, 4 \mathrm{~min})$, the cells were washed once with $1 \mathrm{mM}$ EDTA in CMFS, resuspended in cold CMFS and were gently pipetted. They were filtrated through four layers of gauze and two layers of silk cloth, and washed twice with cold CMFS by centrifugation. The cells were finally suspended in basal assay medium at a density of $3 \times 10^{6} \mathrm{cells} / \mathrm{ml}$. This medium was $\mathrm{Ca}^{2+}$ - and $\mathrm{Mg}^{2+}$-free modified Eagle's MEM (CMF-MEM), which was composed of $6.8 \mathrm{~g}$ $\mathrm{NaCl}, 0.4 \mathrm{~g} \mathrm{KCl}, 1.0 \mathrm{~g}$ glucose, $0.86 \mathrm{~g}$ salt-free Eagle's MEM powder (Nissui, Tokyo) and $2.38 \mathrm{~g}$ HEPES (Dojin, Kumamoto) in 1 liter of triple-distilled water, and was adjusted to $\mathrm{pH} 7.4$ with $1 \mathrm{~N} \mathrm{NaOH}$. Almost all cells in suspensions obtained by such procedures were singly dispersed. All solutions used for assays were filtrated through Millipore filter to render them strictly dust-free.

Neural retinae isolated from embryos were incubated in $1 \mathrm{mM}$ EDTA for $10 \mathrm{~min}$ at room temperature. After additional incubation in $0.5 \%$ crude trypsin in CMFS for $40 \mathrm{~min}$ at $37^{\circ} \mathrm{C}$, the tissues were dissociated by flushing with a pipette. Dispersed cells were treated with $50 \mu \mathrm{g} /$ $\mathrm{ml}$ DNase (Sigma, St. Louis, 1 x crystallized) in CMFS containing $1 \mathrm{mM} \mathrm{MgCl}$ for $10 \mathrm{~min}$ at $37^{\circ} \mathrm{C}$ to remove the DNA released from lysed cells, and washed once with $1 \mathrm{mM}$ EDTA and twice with CMFS. The cells were finally suspended in CMF-MEM to a density of $2 \times 10^{7}$ cells $/ \mathrm{ml}$.

Culture dish. For studying cell-to-cell adhesion (cell aggregation), the condition of excluding cell adhesion to the culture dish was essential. The aggregation dishes used were polyvinyl chloride cylinder (inner diameter $28 \mathrm{~mm}$ ) firmly attached to the bottom of plastic petri dishes (Jintan-Termo, Tokyo). Into each aggregation dish $5 \mathrm{ml}$ of $0.5 \%$ bovine serum albumin (Armour, Chicago, fraction $\mathrm{V}$ ) and $0.8 \% \mathrm{NaCl}$ dissolved in water was added and left overnight in a refrigerator. After removing the solution the dishes were repeatedly rinsed with distilled water. In such albumin-coated dishes, cell adhesion to the substrate was effectively prevented. All test tubes and pipettes used for assaying cell adhesion were also previously coated with albumin as described above.

For studying cell-to-substrate adhesion, Falcon plastic petri dishes $(6 \mathrm{~cm}$ in diameter) were coated with $5 \mathrm{ml}$ of $0.5 \%$ gelatin (Merck) and $0.8 \% \mathrm{NaCl}$ in double distilled water in the same manner as in coating with albumin.

Measurement of cell adhesion. For assaying cell-to-cell adhesion, $0.3 \mathrm{ml}$ of cell suspension was added into each aggregation dish with $2.7 \mathrm{ml}$ of CMF-MEM prewarmed to $37^{\circ} \mathrm{C}$. The final cell density in each dish was $3 \times 10^{5}$ cells $/ \mathrm{ml}$ for fibroblastic cells and $2 \times 10^{6}$ cells $/ \mathrm{ml}$ for neural retina cells. The following method was used for measurement of the rate of cell-to-cell adhesion, unless otherwise noted. The aggregation dishes with cells were placed on a Gyratory Shaker (model G-25, New Brunswick Scientific Co.) and rotated at $80 \mathrm{rpm}$ at $37^{\circ} \mathrm{C}$. After about $30 \mathrm{~min}$, the cells concentrated in the center of each cylinder. A given amount of divalent cation(s) was then added to the cylinder from the stock solution, which determined the zero period of aggregation. Dishes were removed from the Gyratory Shaker at appropriate intervals, and cells were immediately fixed by adding $2 \mathrm{ml}$ of $5 \%$ glutaraldehyde in CMFS at $\mathrm{pH} 8$, under constant medium agitation. This fixation did not cause artificial aggregation or dissociation of cells if the measurement was conducted within a few hours. The method for measuring aggregation is described below.

For assaying cell-to-substrate adhesion, $3 \mathrm{ml}$ of cell suspension was inoculated in each 
gelatin-coated Falcon plastic dish at the final cell density of $3 \times 10^{5} \mathrm{cell} / \mathrm{ml}$. After adding the necessary quantity of divalent cation(s), the dishes were incubated in a water-saturated atmosphere at $37^{\circ} \mathrm{C}$ without agitation. Cells were fixed, following varying incubation intervals, and the number of non-adhering cell counted. Neither further attachment of still non-adhering cells nor detachment of once attached cells occurred after fixation.

Fixed cell suspensions were diluted with $10 \mathrm{ml}$ of CMFS, and the total particle number which included the number of single cells plus the number of aggregates was counted with a Coulter counter (model $Z_{B}$, Coulter Electronics, Hialeah, Fla.) equipped with a $100 \mu$ aperture.

The degree of aggregation was represented by the index Nt/No, where No is the initial particle number applied into each dish and $\mathrm{Nt}$ is the total particle number at the indicated time $(7,10)$. The degree of cell attachment to the substrate was represented as the percentage of unattached cells.

Stock solutions. All divalent cations were prepared as chloride salts. One hundred-fold concentrated stock solutions were prepared in $\mathrm{H}_{2} \mathrm{O}$. Crystallized trypsin (Sigma, type I) and trypsin inhibitor (Sigma, Type I-S) were dissolved in CMF-MEM in 10-fold concentration.

\section{RESULTS}

Effects of $\mathrm{Mg}^{2+}$ and $\mathrm{Ca}^{2+}$ on cell-to-cell adhesion of fibroblastic cells. Fibroblastic cells which hardly aggregated in CMF-MEM started aggregation immediately after addition of $1 \mathrm{mM} \mathrm{Mg}^{2+}$, and the aggregation continued for about 3 hours (Fig. 1). The degree of aggregation was dependent upon the concentration of $\mathrm{Mg}^{2+}$ added, as judged from the $\mathrm{Nt} / \mathrm{No}(\mathrm{t}=60 \mathrm{~min})$ value in different concentrations of $\mathrm{Mg}^{2+}$ in the range between 0.01 and $20 \mathrm{mM}$ (Fig. 2).

When $1 \mathrm{mM} \mathrm{Ca}^{2+}$ was added, aggregation started with a $30 \mathrm{~min}$ lag. After 60 to 90 min of incubation, $\mathrm{Nt} / \mathrm{No}$ value of $\mathrm{Ca}^{2+}$ became almost identical to that in $\mathrm{Mg}^{2+}$, and sometimes even exceeded the $\mathrm{Mg}^{2+}$ value after prolonged incubation (Fig. 1). When

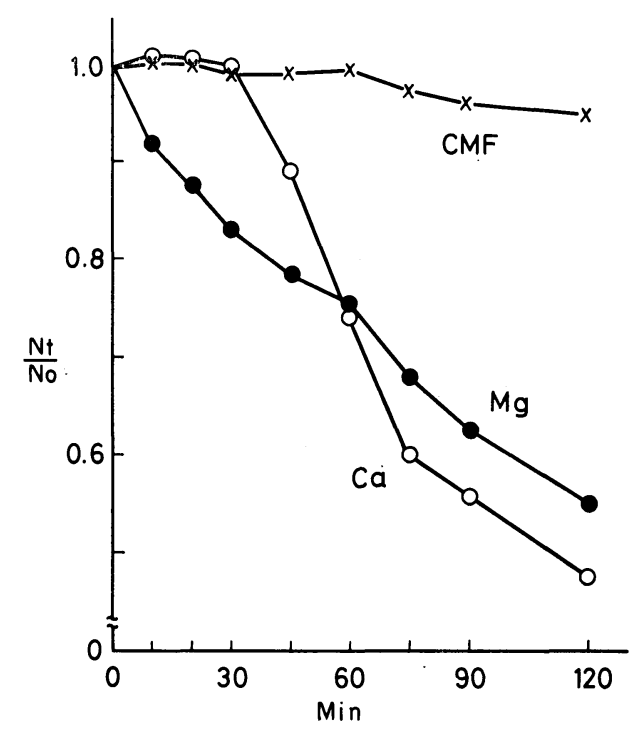

Fig. 1. Aggregation kinetics of fibroblastic cells in $1 \mathrm{mM} \mathrm{Ca}^{2+}, 1 \mathrm{mM} \mathrm{Mg}^{2+}$ or in the absence of both ions (CMF). The experiments were repeated five times, and similar kinetic patterns were obtained. 


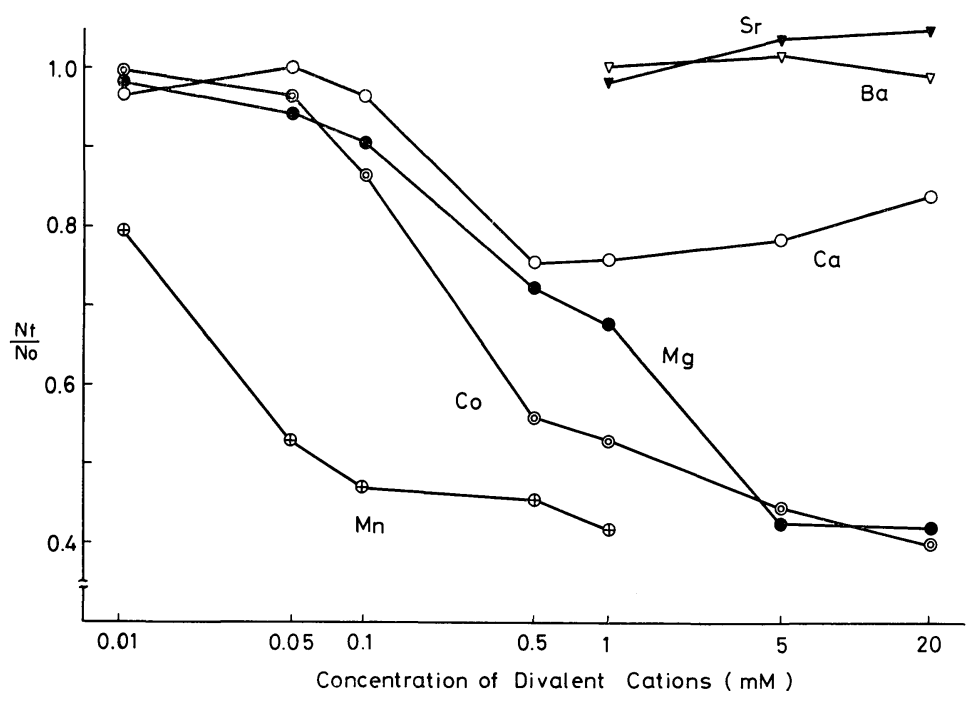

Fig. 2. Comparison of aggregation index Nt/No of fibroblastic cells in various concentrations of six different cations, where $\mathrm{t}$ was $60 \mathrm{~min}$. The figure represents the result of one of three experiments with essentially the same result.

the concentration of $\mathrm{Ca}^{2+}$ was tested in a range 0.01 to $20 \mathrm{mM}$, the maximum effect was obtained at 0.5 and $1 \mathrm{mM}$, and in higher concentrations, the aggregation was somewhat inhibited (Fig. 2).

When $1 \mathrm{mM} \mathrm{Mg}^{2+}$ was added to cells which were previously incubated in CMFMEM for $180 \mathrm{~min}$ at $37^{\circ} \mathrm{C}$, aggregation started immediately and continued at the nearly same rate as in cells without the previous incubation. This result ruled out the possibility that the failure of aggregation in CMF was due to cell death in such a special environment. Aggregation was completely inhibited at $4{ }^{\circ} \mathrm{C}$ in any ionic condition (data not shown). When $0.05 \%$ crystallized trypsin was added in the aggregation medium, the aggregation was completely inhibited in the presence of $\mathrm{Ca}^{2+}$ or $\mathrm{Mg}^{2+}$. Such trypsin effects were abolished with $0.1 \%$ soybean trypsin inhibitor.

Effect of $\mathrm{Mn}^{2+}, \mathrm{Co}^{2+}, \mathrm{Ba}^{2+}$ and $\mathrm{Sr}^{2+}$ on cell-to-cell adhesion. The effect of $\mathrm{Mn}^{2+}, \mathrm{Co}^{2+}$, $\mathrm{Ba}^{2+}$ and $\mathrm{Sr}^{2+}$ on aggregation of fibroblastic cells was compared with the effect of $\mathrm{Mg}^{2+}$ and $\mathrm{Ca}^{2+}$ by obtaining the $\mathrm{Nt} / \mathrm{No}$ value, where $\mathrm{t}$ was $60 \mathrm{~min}$ (Fig. 2). $\mathrm{Mn}^{2+}$ was the most effective ion in comparisons of the lowest effective concentration. The effectiveness of $\mathrm{Co}^{2+}$ was almost the same as that of $\mathrm{Mg}^{2+}$. These three ions were not inhibitory at high concentrations within the tested range. It was also common to these cations that they initiated aggregation without a lag (Fig. 3). In $\mathrm{Sr}^{2+}$ and $\mathrm{Ba}^{2+}$ fibroblastic cells did not aggregate.

Effect of $\mathrm{Ca}^{2+}$ and $\mathrm{Mg}^{2+}$ simultaneously added to medium. The aggregation of fibroblastic cells was carried out in medium containing both $\mathrm{Ca}^{2+}$ and $\mathrm{Mg}^{2+}$ (Fig. 4). The rapid aggregation observed in medium with $\mathrm{Mg}^{2+}$ was inhibited by the coexistence of $\mathrm{Ca}^{2+}$ for $30 \mathrm{~min}$ which corresponded to the lag period of the aggregation in the medium with $\mathrm{Ca}^{2+}$ alone. After $60 \mathrm{~min}$, the $\mathrm{Nt} / \mathrm{No}$ value was intermediate between the two control values with $\mathrm{Ca}^{2+}$ or $\mathrm{Mg}^{2+}$ alone. Then, the $\mathrm{Nt} / \mathrm{No}$ value of $\mathrm{Mg}^{2+}$ plus $\mathrm{Ca}^{2+}$ decreased below the control values, suggesting the additive effect of these ions on the later stage of aggregation. 


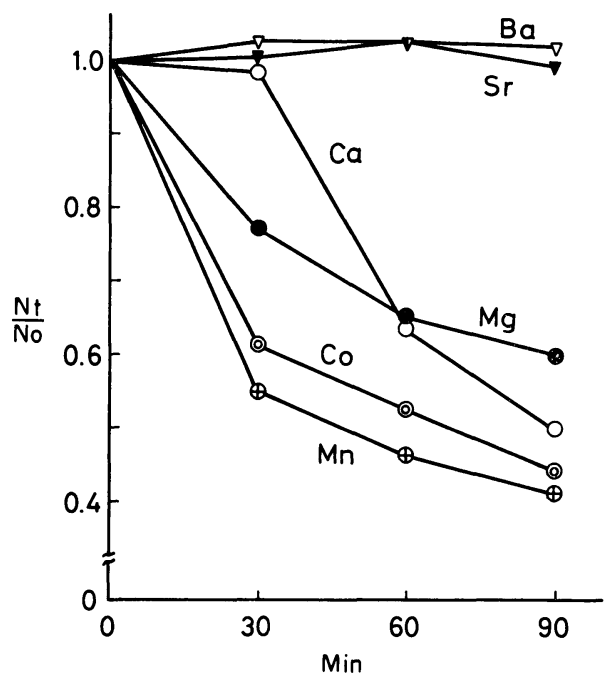

Fig. 3. Aggregation kinetics of fibroblastic cells in six different cations $\left(\mathrm{Mn}^{2+}, 0.1 \mathrm{mM}\right.$; others, $1 \mathrm{mM})$. The figure represents one of two experiments with similar results.

The inhibitory effect of $\mathrm{Ca}^{2+}$ on cell aggregation in the initial stage was shown in another way. When $\mathrm{Ca}^{2+}$ was added to an aggregating cell suspension $30 \mathrm{~min}$ after the addition of $\mathrm{Mg}^{2+}$, the $\mathrm{Nt} / \mathrm{No}$ value immediately increased and the value remained constant for about $20 \mathrm{~min}$, before a sharp drop occurred (Fig. 5). This result strongly suggests that $\mathrm{Ca}^{2+}$ caused a partial dissociation of aggregates previously formed in $\mathrm{Mg}^{2+}$ and temporarily inhibited aggregation. Perhaps the appearance of an initial lag in aggregation by $\mathrm{Ca}^{2+}$ was due to such a $\mathrm{Ca}^{2+}$ inhibitory effect.

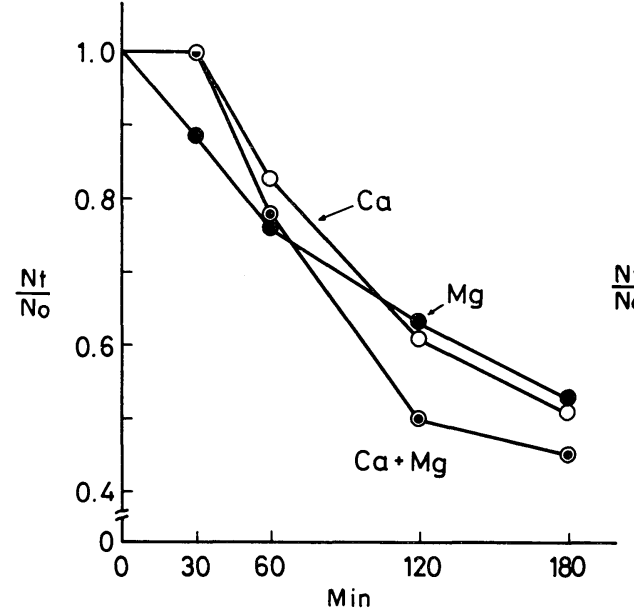

Fig. 4. Aggregation kinetics of fibroblastic cells in the medium with both $1 \mathrm{mM} \mathrm{Mg}^{2+}$ and $1 \mathrm{mM} \mathrm{Ca}^{2+}$. Controls of $1 \mathrm{mM} \mathrm{Mg}^{2+}$ alone or $1 \mathrm{mM} \mathrm{Ca}^{2+}$ alone were conducted using the same cell suspension as the experiment. Essentially the same result was obtained in another assay.

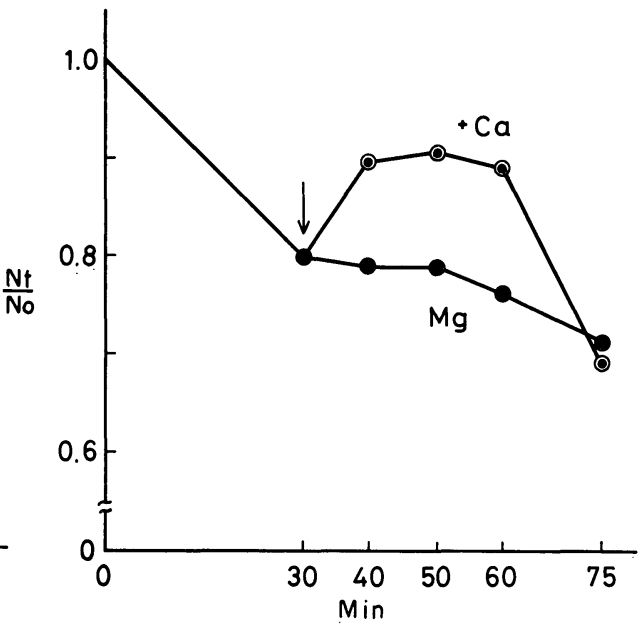

Fig. 5. The effect of $1 \mathrm{mM} \mathrm{Ca}{ }^{2+}$ added to samples of fibroblastic cells under aggregation in $1 \mathrm{mM} \mathrm{Mg}^{2+}$. Note the immediate increase of the aggregation index Nt/No after addition of $\mathrm{Ca}^{2+}$ (arrow). Similar results were obtained in two other experiments. 
Difference in size-distribution between aggregates formed in $\mathrm{Mg}^{2+}$ and $\mathrm{Ca}^{2+}$. Microscopically, the maximum aggregate size formed in the medium with a physiological concentration of $\mathrm{Ca}^{2+}$ was always larger than in the medium with an equimolar concentration of $\mathrm{Mg}^{2+}$, even when the Nt/No value was almost identical (Fig. 6). Such an

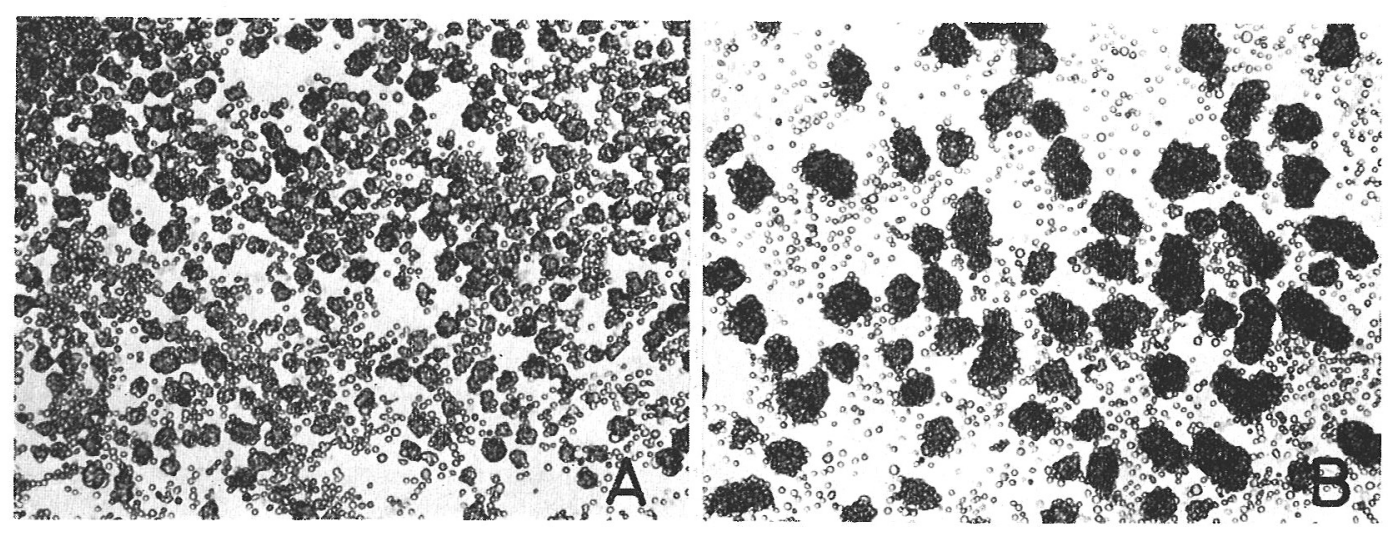

Fig. 6. Photographs of aggregates of fibroblastic cells formed after $120 \mathrm{~min}$ of gyration in $1 \mathrm{mM}$ $\mathrm{Mg}^{2+}(\mathrm{A})$ and $1 \mathrm{mM} \mathrm{Ca}{ }^{2+}(\mathrm{B})$. The $\mathrm{Nt} / \mathrm{No}$ value was 0.47 in $\mathrm{Mg}^{2+}$ and 0.48 in $\mathrm{Ca}^{2+} . \times 50$.

observation was confirmed quantitatively by determining the number of differentsized aggregates with the Coulter counter. The window was set between 15 and 60 . In this range, more than $80 \%$ of particles in "single" cell suspensions were counted at $1 /$ amplification $=4$, and 1 /aperture current $=1$. The remaining particles were detected at a window setting higher than 60 . By increasing the value of the settings fourfold, (1/amp. x 1/a.c.) particles four-fold larger in volume were counted. This process was repeated until all size particles were counted.

Table 1 shows the distribution of the number of aggregates with 4-, 16-, 64- or 256fold volume relative to a "single" cell volume after 120 min of incubation in $\mathrm{Mg}^{2+}$ and $\mathrm{Ca}^{2+}$ media, when the $\mathrm{Nt} / \mathrm{No}$ was almost equal in $1 \mathrm{mM} \mathrm{Mg}{ }^{2+}$ and $1 \mathrm{mM} \mathrm{Ca}{ }^{2+}$.

TABLE 1. Size Distribution of AgGregates IN $\mathrm{Mg}^{2+}$ AND $\mathrm{Ca}^{2+}$ Media

\begin{tabular}{crrrrrr}
\hline \multirow{7}{*}{ Particle size $a$} & \multicolumn{7}{c}{ No. particles/ml medium $\times 10^{-1}$} \\
\cline { 2 - 7 } & $\begin{array}{c}\text { Before } \\
\text { aggregation }\end{array}$ & $1 \mathrm{mM} \mathrm{Mg}^{2+}$ & $1 \mathrm{mM} \mathrm{Ca}^{2+}$ & $2 \mathrm{mM} \mathrm{Mg}^{2+}$ & $2 \mathrm{mM} \mathrm{Ca}^{2+}$ & $\begin{array}{l}1 \mathrm{mM} \mathrm{Mg}^{2+}+ \\
1 \mathrm{mM} \mathrm{Ca}^{2+}\end{array}$ \\
\hline $1 \times$ & 25718 & 15386 & 16204 & 13138 & 18077 & 12919 \\
$4 \times$ & 5957 & 2590 & 1859 & 1906 & 1820 & 1501 \\
$16 \times$ & 17 & 470 & 68 & 415 & 41 & 50 \\
$64 \times$ & 0 & 90 & 148 & 152 & 137 & 76 \\
$256 \times$ & 0 & 0 & 5.3 & 2.7 & 5.3 & 38.7 \\
\hline Total & 31692.0 & 18536.0 & 18288.3 & 15613.7 & 20080.3 & 14584.7 \\
Nt/No & 1.00 & 0.58 & 0.58 & 0.49 & 0.63 & 0.46 \\
\hline
\end{tabular}

a Relative value to the average volume of single cell. Cells after 120 min of gyration were assayed, 
The number of the largest aggregates was greater in $\mathrm{Ca}^{2+}$ than in $\mathrm{Mg}^{2+}$. The number of aggregates in $\mathrm{Mg}^{2+}$ was successively decreased with an increase in size, while the size distribution of the aggregates in $\mathrm{Ca}^{2+}$ showed a peak at the 64-fold aggregate. In $2 \mathrm{mM}$ cation concentration, the maximum size of aggregates was 256 -fold in both $\mathrm{Mg}^{2+}$ and $\mathrm{Ca}^{2+}$. The size distribution of the aggregates, however, was still different in these two media as observed in assays using $1 \mathrm{mM}$ media.

In the medium with both $\mathrm{Ca}^{2+}$ and $\mathrm{Mg}^{2+}$, larger aggregates were formed than those in medium with each ion alone at an equimolar concentration (Table 1). The higher aggregability of cells in medium with both cations, therefore, is not due to the simple increase of divalent cation concentration, but due to the additive action of the two ions on cell adhesion.

Effect of divalent cations on cell-to-substrate adhesion. Our previous paper revealed that $\mathrm{Mg}^{2+}$ was more effective than $\mathrm{Ca}^{2+}$ in promoting adhesion of chick fibroblastic cells to plastic substrate coated with acidic proteins (26). In the present study, the effect of various divalent cations was re-examined on cell adhesion of fibroblastic cells to Falcon plastic dishes coated with gelatin. The kinetics of cell adhesion in $\mathrm{Mg}^{2+}$ or $\mathrm{Ca}^{2+}$ are shown in Fig. 7. As in the case of cell-to-cell adhesion, there was a lag in $\mathrm{Ca}^{2+}$

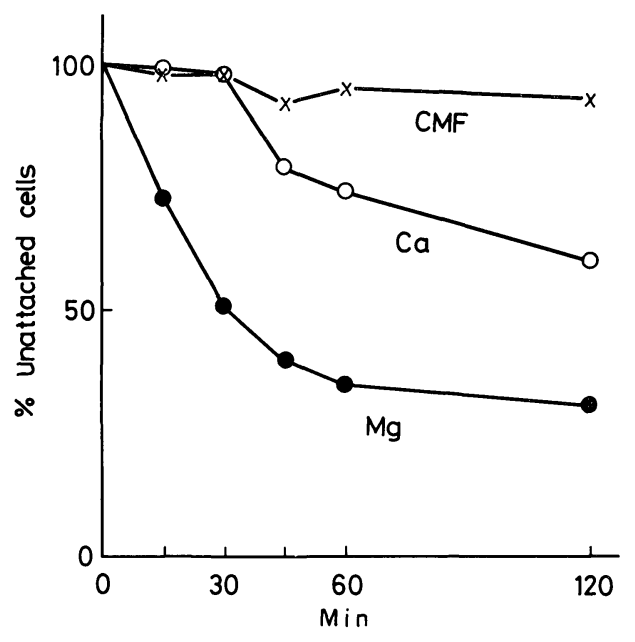

Fig. 7. Kinetics of adhesion of fibroblastic cells to gelatin coated Falcon plastic dishes in $1 \mathrm{mM} \mathrm{Ca}^{2+}$ or $1 \mathrm{mM} \mathrm{Mg}^{2+}$.

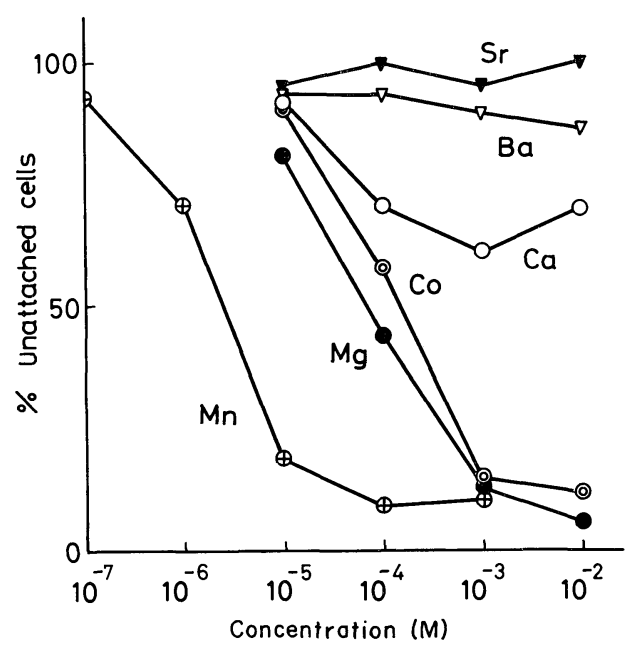

Fig. 8. The effect of six different divalent cations at different concentrations on the cellto-substrate adhesion of fibroblastic cells. Percentages of unattached cells $60 \mathrm{~min}$ after incubation are plotted.

before the start of adhesion. The number of cells adhering to the substrate was always less in $\mathrm{Ca}^{2+}$ than in $\mathrm{Mg}^{2+}$ throughout the incubation period of $120 \mathrm{~min}$, confirming our previous results. The cation effectiveness was $\mathrm{Mn}^{2+}>\mathrm{Co}^{2+} \simeq \mathrm{Mg}^{2+}$ judged from the lowest effective concentration that permitted cell adhesion to the substrate. $\mathrm{Ca}^{2+}$ displayed maximum effect at $1 \mathrm{mM}$ (Fig. 8) but permitted adhesion of only about $40 \%$ of the inoculated population. $\mathrm{Ba}^{2+}$ and $\mathrm{Sr}^{2+}$ were hardly effective.

Effect of divalent cations on cell adhesion of neural retina. Kinetics of aggregation of neural retina cells was measured in the presence of $1 \mathrm{mM} \mathrm{Mg}^{2+}, 1 \mathrm{mM} \mathrm{Ca}^{2+}$ and CMFMEM (Fig. 9). Aggregation of neural retina cells occurred more slowly than fibro- 


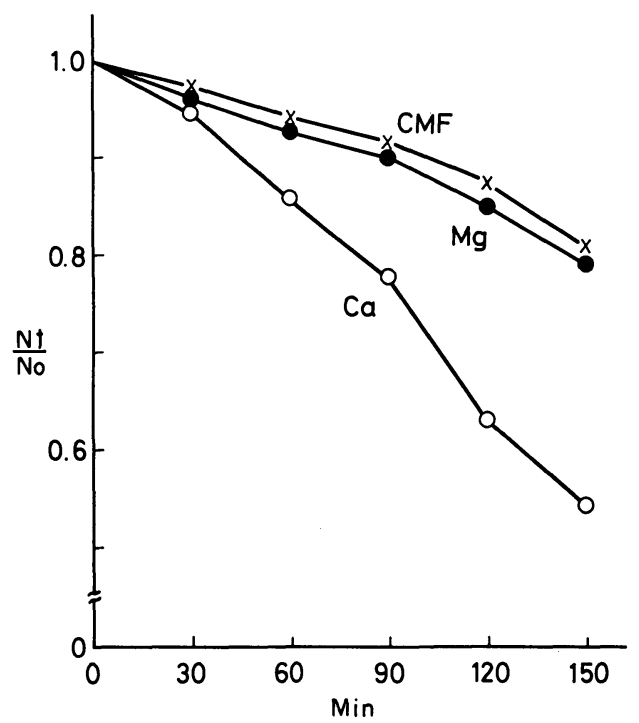

Fig. 9. Aggregation kinetics of neural retina cells in three different media. Divalent cations were added at $1 \mathrm{mM}$.

blastic cells in $\mathrm{Ca}^{2+}$, while the results in $\mathrm{Mg}^{2+}$ were essentially the same as in CMFMEM during the incubation period. Other cations tested, $\mathrm{Mn}^{2+}, \mathrm{Co}^{2+}, \mathrm{Ba}^{2+}$ and $\mathrm{Sr}^{2+}$, were similarly ineffective as $\mathrm{Mg}^{2+}$, although $\mathrm{Mn}^{2+}$ in $10 \mathrm{mM}$ concentration was slightly effective, as judged from the $\mathrm{Nt} / \mathrm{No}$ value $120 \mathrm{~min}$ after inoculation (Table 2).

TABLE 2. EFFECT OF DIVALENT CATIONS ON AGGREGATION OF NEURAL RETINA CELLS

\begin{tabular}{|c|c|c|}
\hline Divalent cations & $\mathrm{Nt} / \mathrm{No}^{a}$ & Ratio to* \\
\hline \multicolumn{3}{|l|}{ Without } \\
\hline divalent cations & $0.83^{*}$ & 1.00 \\
\hline $\mathrm{Mn} \quad 1 \mathrm{mM}$ & 0.79 & 0.95 \\
\hline $10 \mathrm{mM}$ & 0.73 & 0.88 \\
\hline $1 \mathrm{mM}$ & 0.87 & 1.05 \\
\hline $10 \mathrm{mM}$ & 0.81 & 0.98 \\
\hline $1 \mathrm{mM}$ & 0.80 & 0.96 \\
\hline $10 \mathrm{mM}$ & 0.79 & 0.95 \\
\hline $1 \mathrm{mM}$ & 0.58 & 0.70 \\
\hline $10 \mathrm{mM}$ & 0.51 & 0.61 \\
\hline $1 \mathrm{mM}$ & 0.78 & 0.94 \\
\hline $10 \mathrm{mM}$ & 0.80 & 0.96 \\
\hline $1 \mathrm{mM}$ & 0.88 & 1.06 \\
\hline $10 \mathrm{mM}$ & 0.87 & 1.05 \\
\hline
\end{tabular}

$a$ No represents the initial particle number in the dish and $\mathrm{Nt}$ represents the total particle number after incubation.

Assays were performed after $120 \mathrm{~min}$ of incubation. Typical results are shown. The absolute values varied among the three experiments conducted, but the relative differences in cell adhesiveness among the different ionic conditions were reproducible.

A negligible adhesion of neural retina cells to substrate coated with gelatin was observed even after several hours of incubation in the presence of divalent cations effective for adhesion of fibroblasts. Adhesion of appreciable numbers of cells occurred 
TABLE 3. EFFECT OF DIVALENT CATIONS ON ATTACHMENT OF NEURAL RETINA CELlS to GELATINCOATED PLASTIC ${ }^{a}$

\begin{tabular}{|c|c|}
\hline Divalent cations & Unattached cells $(\%)^{b}$ \\
\hline $\begin{array}{l}\text { Without divalent } \\
\text { cations }\end{array}$ & 103 \\
\hline $\mathrm{Mn} \quad 1 \mathrm{mM}$ & 100 \\
\hline $10 \mathrm{mM}$ & 5 \\
\hline $1 \mathrm{mM}$ & 96 \\
\hline $1 \mathrm{mM}$ & 91 \\
\hline $\mathrm{Mg} \quad 1 \mathrm{mM}$ & 103 \\
\hline $10 \mathrm{mM}$ & 96 \\
\hline $\mathrm{Ca} \quad 1 \mathrm{mM}$ & 96 \\
\hline $10 \mathrm{mM}$ & 101 \\
\hline $1 \mathrm{mM}$ & 98 \\
\hline $10 \mathrm{mM}$ & 90 \\
\hline $1 \mathrm{mM}$ & 100 \\
\hline $10 \mathrm{mM}$ & 92 \\
\hline
\end{tabular}

a Dishes were treated overnight with $0.005 \%$ gelatin.

$b$ The number of unattached cells was counted after $60 \mathrm{~min}$ of incubation. Percentages represent the mean of samples taken from three dishes initiated from a common inocula and incubated under the same conditions.

only when one hundred-fold diluted gelatin solution was used for coating. This, however, was observed only in the presence of $10 \mathrm{mM} \mathrm{Mn}^{2+}$ among cations tested (Table 3). When Falcon plastic dishes were coated with fetal calf serum, neural retina cells effectively adhered to the substrate in the presence of $10 \mathrm{mM} \mathrm{Co}^{2+}$, as well as $10 \mathrm{mM}$ $\mathrm{Mn}^{2+}$, while the other cations were still ineffective.

\section{DISCUSSION}

The present study has demonstrated that divalent cation dependence of cell adhesion varied with either the cell type or the adhesion type. The four different cations $\mathrm{Mn}^{2+}$, $\mathrm{Co}^{2+}, \mathrm{Mg}^{2+}$ and $\mathrm{Ca}^{2+}$ ) tested were effective in promoting either the cell-to-cell adhesion or the cell-to-substrate adhesion of fibroblastic cells. For neural retina cells, however, $\mathrm{Ca}^{2+}$ was specifically effective among the above ions in promoting cell-to-cell adhesion, whereas $\mathrm{Mn}^{2+}$ or $\mathrm{Co}^{2+}$ was more effective than the others on cell-to-substrate adhesion as in the case of fibroblastic cell adhesion.

The aggregation of fibroblastic cells occurred rapidly in the presence of $\mathrm{Mn}^{2+}, \mathrm{Co}^{2+}$ or $\mathrm{Mg}^{2+}$. This result is consistent with the report by Armstrong (1) and Hornby (14) which showed a requirement for $\mathrm{Mg}^{2+}$ but not $\mathrm{Ca}^{2+}$ for aggregation of chick embryonic cells. The present study has demonstrated that $\mathrm{Ca}^{2+}$ is also effective although its effect could not be detected in the early stage of aggregation. The action of $\mathrm{Ca}^{2+}$, however, was distinctive from the other ions in following aspects. First, $\mathrm{Ca}^{2+}$ seemed to have an inhibitory effect on cell adhesion, which is probably independent of its adhesion-promoting activity (25). Contraction of cells in $\mathrm{Ca}^{2+}$ may be relevant to such effects (16). Second, the cell adhesion-promoting activity of $\mathrm{Ca}^{2+}$ was less effective at high concentrations. Such property could be attributed to its inhibitory action on cell adhesion, as mentioned earlier. Thirdly, the size distribution pattern of aggregates in $\mathrm{Ca}^{2+}$ was found to be different from that in $\mathrm{Mg}^{2+}$, in which the bigger aggregates 
tended to be formed in $\mathrm{Ca}^{2+}$ than in $\mathrm{Mg}^{2+}$, although the aggregation index $\mathrm{Nt} / \mathrm{No}$ was not different in either ionic condition. This phenomenon suggests that cells undergo somewhat different aggregation procedures in each cation. The experiment using the medium with both ions suggested the presence of different sites for each ion. It should be emphasized here that the third point enumerated above complicates the comparison of cell adhesiveness in different environments. The measurement of cell adhesiveness by using only a single index, e. g., the decrease in total particle number (7), the decrease in single cell number $(5,19)$ or the comparison of the size of aggregates $(18)$, is insufficient for a complete determination of the nature of cell adhesiveness.

The cell adhesion mechanism depending on $\mathrm{Mn}^{2+}{ }_{4} \mathrm{Co}^{2+}$ or $\mathrm{Mg}^{2+}$ is designated here as the "Mg-mechanism" whereas the mechanism rather specifically depending on $\mathrm{Ca}^{2+}$ is designated as the "Ca-mechanism". There are several reasons to assume that the cell-to-substrate adhesion depends mostly on the "Mg-mechanism". The percentage of adhering fibroblastic cells always remained below $40 \%$ in $\mathrm{Ca}^{2+}$, while it was usually higher than $70 \%$ in the $\mathrm{Mg}^{2+}$-group cations at optimum concentrations. Neural retina cells adhered to the substrate only in the presence of $\mathrm{Mn}^{2+}$ or $\mathrm{Co}^{2+}$, while $\mathrm{Ca}^{2+}$ was totally ineffective in promoting the cell-to-substrate adhesion. On the contrary, the "Ca-mechanism" seemed to be more important for cell-to-cell adhesion. The best example for this concept was that neural retina cells specifically required $\mathrm{Ca}^{2+}$ for cell-to-cell adhesion. Moreover, the distinctive effect of $\mathrm{Ca}^{2+}$ in promoting the adhesion of fibroblastic cells was observed particularly in the cell-to-cell adhesion system.

In summary, we suggest that there are two independent mechanisms, a "Mgmechanism" and a "Ca-mechanism," in cell adhesion. Cell-to-cell adhesion of fibroblastic cells can be achieved with either of these mechanisms, while cell-to-substrate adhesion of these cells depends mostly on the "Mg-mechanism." In different types of cells the development of these two mechanisms would be different. In neural retina cells the "Mg-mechanism" may be relatively less developed, so that the "Ca-mechanism" could have been more easily detected.

It remains to be investigated which kind of cellular physiological activity is related to each hypothetical mechanism. It should be emphasized here that the order of effectiveness of various divalent cations for promoting cell-to-substrate adhesion, $\mathrm{Mn}^{2+}$ $>\mathrm{Co}^{2+} \simeq \mathrm{Mg}^{2+}>\mathrm{Ca}^{2+}$, is parallel to the order for enhancing pseudopodia formation and spreading of cells $(22,26,28)$. The importance of the tip of pseudopodia as a site of cell-to-substrate adhesion has often been pointed out $(9,13,22,23)$. It has also been theoretically suggested that pseudopodia formation is a necessary prerequisite for close contact of apposed cell surfaces $(11,20)$. Therefore, "Mg-mechanism" is likely to be associated with the motile activity of the cell surface.

The situation is still more speculative as to the nature of the "Ca-mechanism." The possibility that $\mathrm{Ca}^{2+}$ acts as an intercellular bridge (24) or that this ion is a necessary component for the function of intercellular macromolecules $(8,25,27)$ to bind apposed cell surfaces should be taken into consideration in speculations on the nature of the "Ca-mechanism."

Acknowledgment. We wish to acknowledge Dr. T.S. Okada for his critical discussion and for reading the manuscript. We are also indebted to Dr. R.E. Pagano for his critical reading of the manuscript. We cordially thank Mrs. S. Yamamoto for her help in its preparation. 


\section{REFERENCES}

1. Armstrong, P.B. On the role of metal cations in cellular adhesion: Effect on cell surface charge. J. Exp. Zool. 163, 99-110, 1966

2. Armstrong, P.B. and D.P. Jones. On the role of metal cations in cellular adhesion: Cation specificity. J. Exp. Zool. 167, 275-282, 1968

3. Bryant, R.E. Divalent cation requirements for leukocyte adhesiveness. Proc. Soc. Exp. Biol. Med. 130, 975-977, 1969

4. Collins, M. Electrokinetic properties of dissociated chick embryo cells. II. Calcium ion binding by neural retina cells. J. Exp. Zool. 163, 39—48, 1966

5. CUrtis, A.S.G. and M.F. Greaves. The inhibition of cell aggregation by a pure serum protein. J. Embryol. Exp. Morphol. 13, 309-326, 1965

6. Curtis, A.S.G. The Cell Surface: Its Molecular Role in Morphogenesis, Logos Press, London, 1967

7. Curtis, A.S.G. The measurement of cell adhesiveness by an absolute method. J. Embryol. Exp. Morphol. 22, 305-325, 1969

8. Deman, J.J., E.A. Bruynell and M.M. Marrel. A study on the mechanism of intercellular adhesion. Effects of neuraminidase, calcium and trypsin on the aggregation of suspended Hela cells. J. Cell Biol. 60, 641-652, 1974

9. DiPasquale, A and B.B. Pell Jr. The upper cell surface: Its inability to support active cell movement in culture. J. Cell Biol. 62, 198-212, 1974

10. Edwards, J. Intercellular adhesion. In New Techniques in Biophysics and Cell Biology, Vol. 1, ed. PAIN, R.H. and B.J. Smith, A Wiley-Interscience Publication, London, pp 1-27, 1973

11 Good, R.J. Theory of adhesion of cells and spontaneous sorting-out of mixed cell aggregates. J. Theor. Biol. 37, 413-434, 1972

12. Gurvin, J.E. Effects of divalent cations on adhesiveness of rat polymorphonuclear neutrophils in vitro. J. Cell. Physiol. 72, 197-212, 1968

13. Harris, A. Location of cellular adhesions to solid substrate. Develop. Biol. 35, 97-114, 1973

14. Hornby, J.E. Measurement of cell adhesion. II. Quantitative study of the effect of divalent ions on cell adhesion. J. Embryol. Exp. Morphol. 30, 511-518, 1973

15. Humphrey, T. Chemical dissociation and in vitro reconstruction of sponge cell adhesion. I. Isolation and functional demonstration of the components involved. Develop. Biol. 8, 27-47, 1963

16. Jones, B.M. A unifying hypothesis of cell adhesion. Nature 212, 362 - 365, 1966

17. Madjanova, E.A. and A.G. Malenkov. Alteration of properties of cell contacts during progression of hepatomas. Exp. Cell Res. 76, 305-314, 1973

18. Moscona, A. Rotation-mediated histogenetic aggregation of dissociated cells. A quantifiable approach to cell interactions in vitro. Exp. Cell Res. 22, 455-475, 1961

19. OrR, C.W. and S. Roseman. Intercellular adhesion. I. A quantitative assay for measuring the rate of adhesion. J. Membr. Biol. 1, 109-124, 1969

20. PethicA, B.A. The physical chemistry of cell adhesion. Exp. Cell Res. Suppl. 8, 123-140, 1961

21. Puck, T.T., S.J. Cieciura and A. Robinson. Genetics of somatic mammalian cells. III. Longterm cultivation of euploid cells from human and animal subjects. J. Exp. Med. 108, 945—956, 1958

22. Rabinovitch, M. and M.J. DeStefano. Manganese stimulates adhesion and spreading of mouse sarcoma I ascites cells. J. Cell Biol. 59, 165-176, 1973

23. Rabinovitch, M. and M.J. DeStefano. Macrophage spreading in vitro. II. Manganese and other metals as inducers or as co-factors for induced spreading. Exp. Cell Res. 79, 423-430,1973

24. SteInberG, M.S. On the chemical bonds between animal cells. A mechanism for type-specific association. Am. Nat. 92, 65-81, 1958

25. Steinberg, M.S., P.B. Armstrong and R.E. Granger. On the recovery of adhesiveness by trypsin-dissociated cells. J. Membr. Biol. 13, 97-128, 1973

26. TAKEICHI, M. and T.S. OKADA. Roles of magnesium and calcium ions in cell-to-substrate adhesion. Exp. Cell Res. 74, 51-60, 1972

27. Weinbaum, G. and M.M. Burger. Two component system for surface guided reassociation of animal cells. Nature, 244, 510-512, 1973 
28. YASUDA, K. Studies on the factors affecting cellular spreading upon culture-substrate. I. The effects of divalent cations and conditioned medium on cellular spreading. J. Cell Sci. 15, 269278,1974

(Received for publication, April 3, 1976) 